\title{
Intermediate Temperature Fluids Life Tests - Experiments
}

\author{
William G. Anderson*, Richard W. Bonner ${ }^{\dagger}$, Peter M. Dussinger ${ }^{\ddagger}$, John R. Hartenstine ${ }^{\S}$, and David B. Sarraf ${ }^{* *}$ \\ Advanced Cooling Technologies, Inc., Lancaster, PA 17601 \\ Ivan E. Locci ${ }^{\dagger \dagger}$ \\ NASA Glenn Research Center, Cleveland, OH 44135
}

\begin{abstract}
There are a number of different applications that could use heat pipes or loop heat pipes (LHPs) in the intermediate temperature range of 450 to $725 \mathrm{~K}\left(170\right.$ to $\left.450^{\circ} \mathrm{C}\right)$, including space nuclear power system radiators, fuel cells, and high temperature electronics cooling. Historically, water has been used in heat pipes at temperatures up to about $425 \mathrm{~K}\left(150^{\circ} \mathrm{C}\right)$. Recent life tests, updated below, demonstrate that titanium/water and Monel/water heat pipes can be used at temperatures up to $550 \mathrm{~K}\left(277^{\circ} \mathrm{C}\right)$, due to water's favorable transport properties. At temperatures above roughly $570 \mathrm{~K}\left(300^{\circ} \mathrm{C}\right)$, water is no longer a suitable fluid, due to high vapor pressure and low surface tension as the critical point is approached. At higher temperatures, another working fluid/envelope combination is required, either an organic or halide working fluid. An electromotive force method was used to predict the compatibility of halide working fluids with envelope materials. This procedure was used to reject aluminum and aluminum alloys as envelope materials, due to their high decomposition potential. Titanium and three corrosion resistant superalloys were chosen as envelope materials. Life tests were conducted with these envelopes and six different working fluids: $\mathrm{AlBr}_{3}, \mathrm{GaCl}_{3}, \mathrm{SnCl}_{4}, \mathrm{TiCl}_{4}, \mathrm{TiBr}_{4}$, and eutectic diphenyl/diphenyl oxide (Therminol VP-1/Dowtherm A). All of the life tests except for the $\mathrm{GaCl}_{3}$ are ongoing; the $\mathrm{GaCl}_{3}$ was incompatible. As the temperature approaches $725 \mathrm{~K}\left(450^{\circ} \mathrm{C}\right)$, cesium is a potential heat pipe working fluid. Life tests results are also presented for cesium/Monel 400 and cesium/70-30 copper/nickel heat pipes operating near $750 \mathrm{~K}\left(477^{\circ} \mathrm{C}\right)$. These materials are not suitable for long term operation, due to copper transport from the condenser to the evaporator.
\end{abstract}

$\begin{array}{ll}\quad \text { Nomenclature } \\ E_{P_{-} M_{x} X_{y}}(T) & =\text { decomposition potential of the metallic halide } \mathrm{M}_{\mathrm{x}} \mathrm{X}_{\mathrm{y}} \text { at the reaction temperature } T(\mathrm{~V}) \\ \Delta \mathrm{E} & =\text { electromotive force difference }(\mathrm{V}) \\ \Delta \mathrm{E}^{0} & =\text { standard electromotive force difference }(\mathrm{V}) \\ \mathrm{M} & =\text { Merit number, } \mathrm{W} / \mathrm{m}^{2} \\ M_{b} X_{c} & =\text { halide of metal } M_{b} \text { (working fluid) } \\ M_{\mathrm{a}} X_{c p} & =\text { halide of metal } M_{a} \text { (reaction product) } \\ \rho_{\mathrm{L}} & =\text { Liquid density, } \mathrm{kg} / \mathrm{m}^{3} \\ \sigma & =\text { Surface tension, } \mathrm{n} / \mathrm{m} \\ \lambda & =\text { Latent heat, } \mathrm{J} / \mathrm{kg} \\ \mu_{\mathrm{L}} & =\text { Liquid viscosity, Pa }\end{array}$

\footnotetext{
* Group Leader, Aerospace Products Group, 1046 New Holland Ave, AIAA Member.

${ }^{\dagger}$ R\&D Engineer, Engineering Services and Products, 1046 New Holland Ave.

* Manager, Custom Products, 1046 New Holland Ave.

$\S$ Manager, Engineering Services and Products, 1046 New Holland Ave.

** Senior Engineer, Custom Products, 1046 New Holland Ave.

${ }^{\dagger \dagger}$ Principal Research, Dept. of Materials Science.
} 


\section{Introduction}

$\mathrm{T}$ he intermediate temperature region for heat pipes is generally defined as 450 to $725 \mathrm{~K}\left(170\right.$ to $\left.450^{\circ} \mathrm{C}\right)$. At temperatures above $725 \mathrm{~K}\left(450^{\circ} \mathrm{C}\right)$, alkali metal heat pipes start to become effective. As the temperature is lowered, the vapor pressure and vapor density of the alkali metals are decreased. Below about $725 \mathrm{~K}\left(450^{\circ} \mathrm{C}\right)$, the vapor density is so low that the vapor sonic velocity limits the heat transfer. The heat pipe (or LHP) vapor velocity becomes too large to be practical for alkali metals in the intermediate temperature range.

Historically, water was used at temperatures up to about $425 \mathrm{~K}\left(150^{\circ} \mathrm{C}\right)$. More recently, it has been shown that water can be used with titanium or Monel envelopes at temperatures up to $550 \mathrm{~K}\left(277^{\circ} \mathrm{C}\right.$ ) (Anderson et al., 2006). While water heat pipes can operate at temperatures up to $570 \mathrm{~K}\left(300^{\circ} \mathrm{C}\right)$, their effectiveness starts to drop off above $500 \mathrm{~K}\left(227^{\circ} \mathrm{C}\right)$, due to the decrease in the surface tension.

This paper will review current life tests on fluids covering the span from water to cesium. Fluid properties are shown in Table 1. A companion paper (Anderson, 2007) reviews previous intermediate temperature fluid heat pipe life tests.

Table 1. Properties of Candidate Heat Pipe Fluids.

\begin{tabular}{|l|c|c|c|c|c|}
\hline Fluid & Formula & $\begin{array}{c}\text { Melting } \\
\text { Point } \\
\text { K }\end{array}$ & $\begin{array}{c}\text { Boiling } \\
\text { Temp. } \\
\text { K }\end{array}$ & $\begin{array}{c}\text { Critical } \\
\text { Temp. } \\
\text { K }\end{array}$ & $\begin{array}{c}\text { Critical Press. } \\
\text { atm }\end{array}$ \\
\hline Water & $\mathrm{H} 2 \mathrm{O}$ & 273 & 373 & 647 & 218.3 \\
\hline Tin Tetrachloride & $\mathrm{SnCl4}$ & 240 & 388 & 592 & 37 \\
\hline Titanium Tetrachloride & $\mathrm{TiCl} 4$ & 243 & 409.6 & 638 & 46 \\
\hline Gallium Trichloride & $\mathrm{GaCl} 3$ & 351 & 474 & 694 & \\
\hline Titanium Tetrabromide & $\mathrm{TiBr} 4$ & 312 & 506 & 795.7 & \\
\hline Aluminum Tribromide & $\mathrm{AlBr} 3$ & 370 & 528 & 763 & 85.5 \\
\hline Eutectic Diphenyl/Diphenyl Oxide & & 285 & 530 & 770 & 31 \\
\hline Antimony Tribromide & $\mathrm{SbBr} 3$ & 370 & 553 & 1178 & 55 \\
\hline Antimony Trichloride & $\mathrm{SbCl3}$ & 346 & 556 & 794 & \\
\hline Cesium & $\mathrm{Cs}$ & 302 & 941 & 2045 & 114.7 \\
\hline
\end{tabular}

\section{Titanium/Water and Titanium/Monel Life Tests}

Titanium, titanium alloys, Monel 400, and Monel K500 have higher yield strength and lower density than copper. As discussed below, they have been shown to be compatible with water, hence can be used in thinner and lighter weight heat pipes than copper at a given operating temperature and working fluid vapor pressure. Anderson, Dussinger, Bonner, and Sarraf (2006) started a series of life tests with commercially pure (CP) titanium, titanium alloys, Monel 400, and Monel K-500. The life test results are updated below. The materials under test include:

- $\quad$ Ti CP-2 Heat Pipe, with CP Titanium Screen

- Monel K500 Heat Pipe, with Monel 400 Screen

- $\quad$ Ti Grade 5 Cylinder (6\% Aluminum, 4\% Vanadium), with CP Titanium Screen

- $\quad$ Ti Grade 7 Cylinder ( $0.2 \%$ Pd), with CP Titanium Screen

- $\quad$ Ti CP-2 Cylinder, with 21S foil and CP Titanium Screen

- $\quad$ Ti Grade 9 cylinder (3\% Aluminum, 2.5\% Vanadium) with CP Titanium Screen

- $\quad$ Ti CP-2 Heat Pipe, with Sintered Cylindrical Wick

- Monel 400 Heat Pipe, with Monel 400 Screen

- Monel K500 Heat Pipe, with sintered Monel 400 wick

- Monel 400 Heat Pipe, with sintered Monel 400 wick

Table 2 shows the different life test pipes on test. Monel 400 is a solid solution alloy with roughly $63 \%$ nickel and 30\% copper. It is a single-phase alloy, since the copper and nickel are mutually soluble in all proportions. It can only be hardened by cold working. Monel K500 is a similar nickel-copper alloy, with the addition of small amounts of aluminum and titanium that give greater strength and hardness. The system is age-hardened by heating 
so that small particles of $\mathrm{Ni3}(\mathrm{Ti}, \mathrm{Al})$ are precipitated throughout the matrix, increasing the strength of the material. The material must be annealed before welding, for ductile welds.

Table 2. Titanium/Water and Monel/Water Life Tests.

\begin{tabular}{|c|c|c|c|c|c|}
\hline Quantity & Wall Material & $\begin{array}{l}\text { End cap/ } \\
\text { Fill Tube }\end{array}$ & Wick & $\begin{array}{c}\text { Operating } \\
\text { Temperature }\end{array}$ & Operating Hours \\
\hline 4 & Monel K 500 & Monel 400 & $\begin{array}{c}200 \times 200 \text { Monel } 400 \text { Screen } \\
0.064 \mathrm{~mm} \text { wire }\end{array}$ & $\begin{array}{c}550 \& 500 \mathrm{~K} \\
\left(277 \& 227^{\circ} \mathrm{C}\right)\end{array}$ & 21,240 hours \\
\hline 4 & $\mathrm{CP}-2 \mathrm{Ti}$ & CP-Ti & $\begin{array}{c}\text { 150x150CP-Ti Screen } \\
0.069 \mathrm{~mm} \text { wire }\end{array}$ & $\begin{array}{c}550 \& 500 \mathrm{~K} \\
\left(277 \& 227^{\circ} \mathrm{C}\right)\end{array}$ & 21,240 hours \\
\hline 4 & $\mathrm{CP}-2 \mathrm{Ti}$ & CP-Ti & $\begin{array}{c}\text { Sintered Titanium } \\
-35+60 \text { Mesh CP-2 } \\
\end{array}$ & $550 \mathrm{~K}\left(277^{\circ} \mathrm{C}\right)$ & 12,797 hours \\
\hline 2 & $\mathrm{CP}-2 \mathrm{Ti}$ & CP-Ti & $\begin{array}{c}100 \times 100 \mathrm{CP}-\mathrm{Ti} \text { Screen } \\
0.05 \mathrm{~mm} \text { wire }\end{array}$ & $550 \mathrm{~K}\left(277^{\circ} \mathrm{C}\right)$ & 1996/10,112 hrs. \\
\hline 2 & \begin{tabular}{|c|} 
CP-2 Ti \\
21 S Foil Inside
\end{tabular} & CP-Ti & $\begin{array}{c}100 \times 100 \mathrm{CP}-\mathrm{Ti} \text { Screen } \\
0.05 \mathrm{~mm} \text { wire }\end{array}$ & $550 \mathrm{~K}\left(277^{\circ} \mathrm{C}\right)$ & 12,797 hours \\
\hline 2 & Grade $5 \mathrm{Ti}$ & CP-Ti & $\begin{array}{c}100 \times 100 \text { CP-Ti Screen } \\
0.05 \mathrm{~mm} \text { wire }\end{array}$ & $550 \mathrm{~K}\left(277^{\circ} \mathrm{C}\right)$ & 12,797 hours \\
\hline 2 & Grade $7 \mathrm{Ti}$ & CP-Ti & $\begin{array}{c}100 \times 100 \mathrm{CP}-\mathrm{Ti} \text { Screen } \\
0.05 \mathrm{~mm} \text { wire }\end{array}$ & $550 \mathrm{~K}\left(277^{\circ} \mathrm{C}\right)$ & 12,797 hours \\
\hline 2 & Grade $9 \mathrm{Ti}$ & CP-Ti & $\begin{array}{c}100 \times 100 \mathrm{CP}-\mathrm{Ti} \text { Screen } \\
0.05 \mathrm{~mm} \text { wire }\end{array}$ & $550 \mathrm{~K}\left(277^{\circ} \mathrm{C}\right)$ & 8,640 hours \\
\hline 2 & Monel 400 & Monel 400 & $\begin{array}{c}\text { 120x120 Monel } 400 \text { Screen } \\
0.05 \mathrm{~mm} \text { wire } \\
\end{array}$ & $550 \mathrm{~K}\left(277^{\circ} \mathrm{C}\right)$ & 8,136 hours \\
\hline 2 & Monel K 500 & Monel 400 & $\begin{array}{c}120 \times 120 \text { Monel } 400 \text { Screen } \\
0.05 \mathrm{~mm} \text { wire }\end{array}$ & $550 \mathrm{~K}\left(277^{\circ} \mathrm{C}\right)$ & 7,296 hours \\
\hline 1 & Monel 400 & Monel 400 & $\begin{array}{c}-100+170 \text { Mesh Monel } 400 \\
\text { Powder }\end{array}$ & $550 \mathrm{~K}\left(277^{\circ} \mathrm{C}\right)$ & 6,408 hours \\
\hline 2 & Monel K 500 & Monel 400 & $\begin{array}{c}-100+170 \text { Mesh Monel } 400 \\
\text { Powder }\end{array}$ & $550 \mathrm{~K}\left(277^{\circ} \mathrm{C}\right)$ & 6,408 hours \\
\hline
\end{tabular}

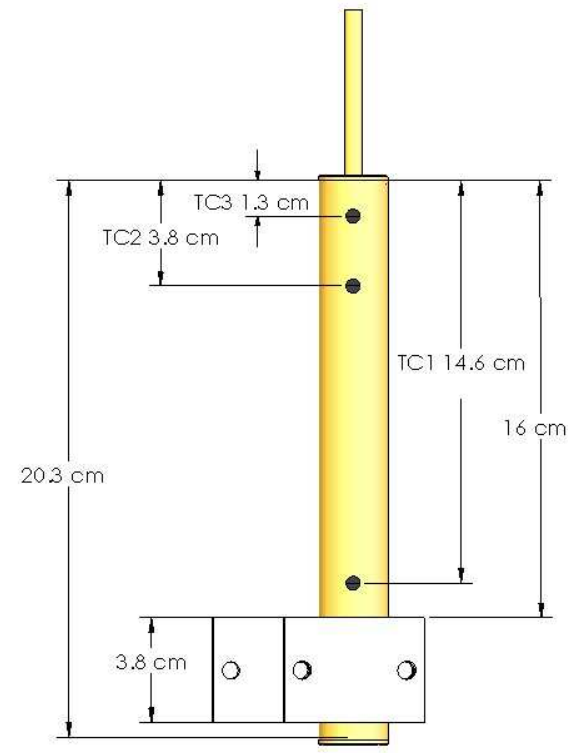

Figure 1. Location of Thermocouples and Heater Block, titanium and Monel heat pipes. 
The experimental setup is shown in Figure 1. Note that the heat pipe operating temperature is dropped to $340 \mathrm{~K}$ $\left(70^{\circ} \mathrm{C}\right)$, before the measurements. With this much lower temperature and vapor pressure, the non-condensable gas expands, making it easier to detect. Typical results are shown in Figures 2 and 3 for Monel and a titanium alloy, respectively. The Monel pipes have shown no signs of gas generation. As shown in Figure 3, the titanium heat pipes all generated gas initially. This was believed to be a result of a passivation process that produced titanium oxide on the surface of the heat pipe. The gas was removed from all of these pipes by heating to about $115^{\circ} \mathrm{C}$ and venting them. The thermocouples are monitored to verify that the non-condensable gas has been forced out of the condenser by the pressure difference. The heat pipe fill tube is then resealed.

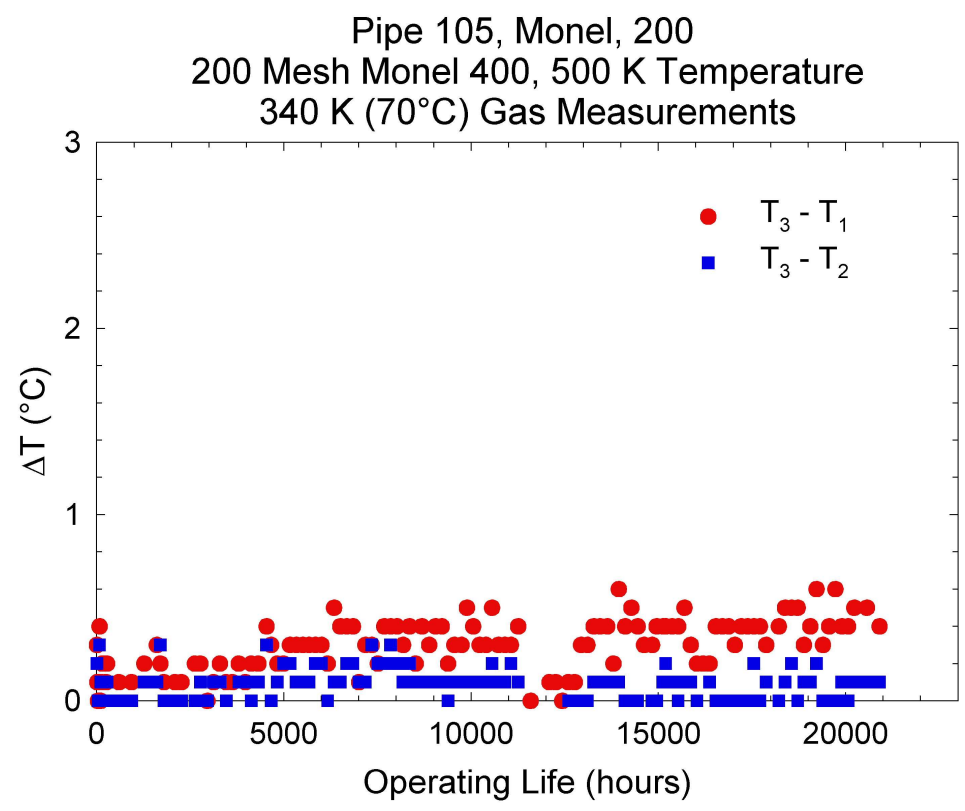

Figure 2. Low Temperature (Non-Condensable Gas) Measurements for Monel /Water Heat Pipe 105, Operating at $500 \mathrm{~K}$.

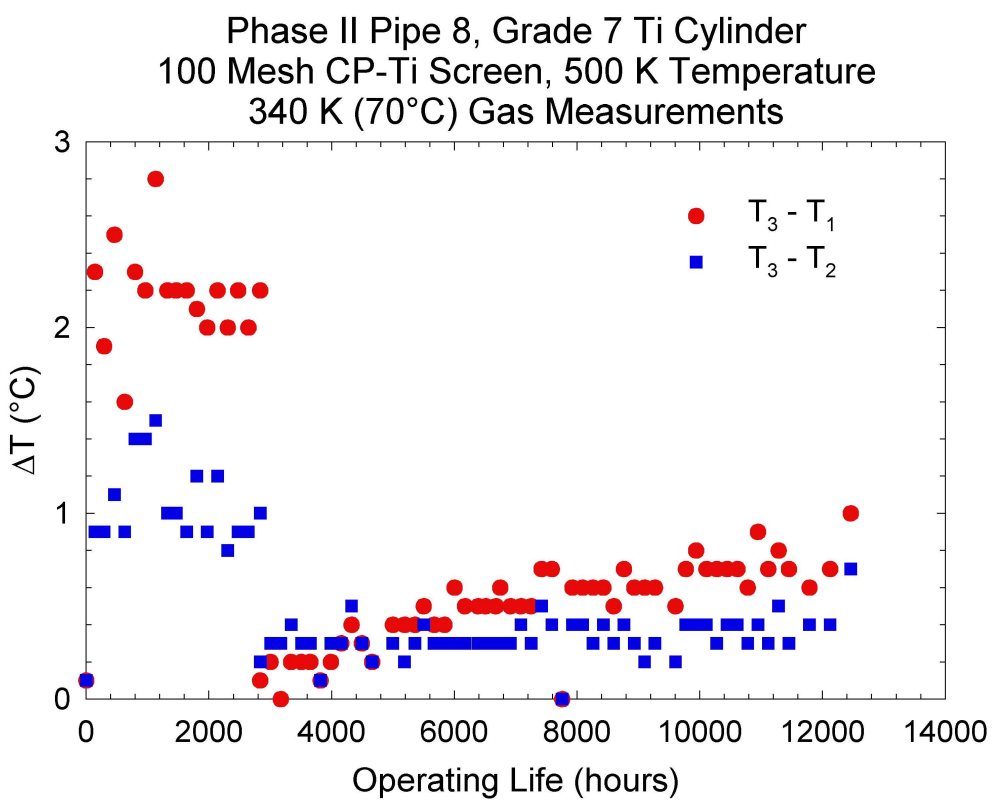

Figure 3. Low Temperature (Non-Condensable Gas) Measurements for Grade 7 Titanium Cylinder/CPTitanium Screen/Water Heat Pipe 3, Operating at 550 K. Purged after 3509 hours of operation. 


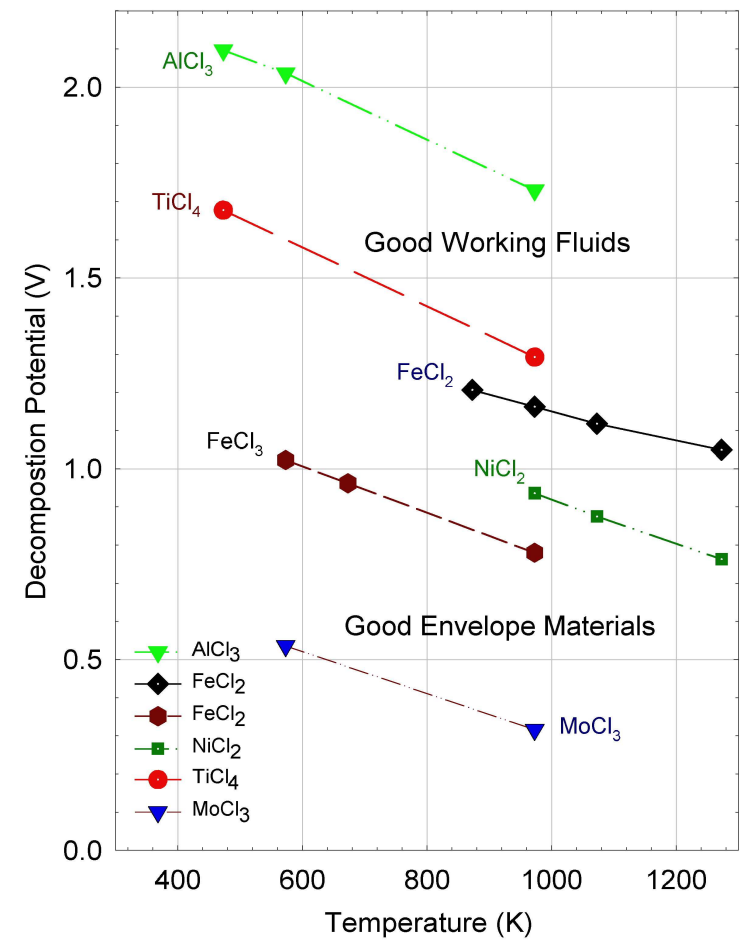

Figure 4. Good Working Fluids (From a Compatibility Standpoint) Have High Decomposition Potentials, While Halides/Salts of Good Envelope Materials Have Low Decomposition Potentials.
In addition to these tests, an additional three $\mathrm{CP}$ titanium/water heat pipes were fabricated with solid groove wicks (Anderson, Dussinger, Bonner, and Sarraf, 2006). The heat pipe performance was measured, then these heat pipes were put on life test at $500 \mathrm{~K}\left(227^{\circ} \mathrm{C}\right)$ (Sanzi, 2007). All three heat pipes continue to be stable after $2600+$ hours of operation with no significant degradation in $\Delta \mathrm{T}$ measured from end to end (Jaworske, 2007). Approximately 45 cycles are on each heat pipe, from ambient to $500 \mathrm{~K}$. As of 4/3/07 HP 1 with 19 grooves has 2636 hours, HP 2 with 23 grooves has 2606 hours, and HP 3 with 17 grooves has 2630 hours. All heat pipes are now operating continuously.

\section{Halides}

A halide is a compound of the type MX, where M may be another element or organic compound, and X may be fluorine, chlorine, bromine, iodine, or astatine. Starting with Saaski and Owarski (1977), a number of researchers have suggested that halides are potential heat pipe fluids. They are attractive because they are more stable at high temperatures than organic working fluids, and because their Merit number peaks in the intermediate temperature range. The merit number (liquid transport factor) is a means of ranking heat pipe fluids, with higher merit number more desirable:

$$
M=\frac{\rho_{L} \sigma \lambda}{\mu_{L}}
$$

Information on halide properties can be found in Anderson et al (2004) and Devarakonda and Anderson (2005).

\section{A. Halide Prediction Method}

Saaski and Owzarsky (1977) proposed an electrochemical method to predict the compatibility of halide working fluids with envelope materials. Tarau et al. (2007) found that this procedure had good agreement with previous life tests. The procedure calculates the electromotive force difference of the reaction between the working fluid and envelope. The standard electromotive force difference or the potential difference, $\Delta \mathrm{E}^{0}$, is the difference between the decomposition potentials of the two halides, the metal envelope halide, $\mathrm{M}_{\mathrm{a}} \mathrm{X}_{\mathrm{cp}}$ and the working fluid, $\mathrm{M}_{\mathrm{b}} \mathrm{X}_{\mathrm{c}}$ :

$$
\Delta E^{o}=E_{P_{-} M_{a} X_{c p}}(T)-E_{P_{-} M_{b} X_{c}}(T)
$$

The standard EMF difference, $\Delta \mathrm{E}^{0}$ is the decomposition potential of the envelope minus the decomposition potential of the fluid. If the standard EMF difference, $\Delta \mathrm{E}^{0}$, is positive, then the reaction can proceed spontaneously and the wall will react chemically. When the standard EMF difference is negative, the probability of spontaneous reaction decreases significantly. This gives the following working fluid/envelope material selection criterion: The envelope material halide should have a lower decomposition potential than the working fluid halide. This is shown in Figure 4. $\mathrm{AlCl}_{3}$ and $\mathrm{TiCl}_{4}$ have a high decomposition potential, so they are good working fluids. Molybdenum and iron have a low decomposition potential, so should be good envelope materials. 
Table 3. Comparison of Previous Halide Life Tests and Predictions.

\begin{tabular}{|c|c|c|c|c|}
\hline Halide & 6061 Aluminum & Mild Steel & 304 SS Screen (Ni) & Titanium \\
\hline \multirow[t]{2}{*}{$\mathrm{AlBr}_{3}$} & $\begin{array}{l}6061 \text { Incomp./500 K } \\
5052 \text { Failed/4,290 } \\
\text { hrs. } / 500 \mathrm{~K}^{3}\end{array}$ & & & $\begin{array}{l}\text { No, Ti/Al compounds } \\
\text { (different mechanism) }\end{array}$ \\
\hline & $\begin{array}{l}\text { Partially Agree (attacked } \\
\text { grains) }\end{array}$ & & & $\begin{array}{l}\mathrm{AlCl}_{3} \text { is slightly } \\
\text { unstable }\end{array}$ \\
\hline \multirow[t]{2}{*}{$\mathrm{SbCl}_{3}$} & Incomp. $/ 500 \mathrm{~K}^{2}$ & Incomp./5,000 hrs./476 K ${ }^{2}$ & Incomp./5,000 hrs./476 K ${ }^{2}$ & \\
\hline & Agree & reacted with SS Wick & Agree & \\
\hline \multirow[t]{2}{*}{$\mathrm{SbBr}_{3}$} & & & & $\begin{array}{l}\text { Incomp./5000 } \\
\text { hours } / 500 \mathrm{~K}^{3}\end{array}$ \\
\hline & & & & Agree \\
\hline \multirow[t]{2}{*}{$\mathrm{SnCl}_{4}$} & Incomp./432 $\mathrm{K}^{2}$ & 27,750 hrs. $/ 429 \mathrm{~K}^{2}$ & 27,750 hrs. $/ 429 \mathrm{~K}^{2}$ & \\
\hline & Agree & Agree & Agree & \\
\hline \multirow[t]{2}{*}{$\mathrm{TiCl}_{4}$} & Incomp. $/ 438 \mathrm{~K}^{2}$ & $28,540 \mathrm{hrs} . / 432 \mathrm{~K}^{2}$ & $28,540 \mathrm{hrs} . / 432 \mathrm{~K}^{2}$ & $4,019 \mathrm{hrs} . / 500 \mathrm{~K}^{3}$ \\
\hline & Agree & Agree & Agree & Agree \\
\hline
\end{tabular}

${ }^{1}$ Locci et al., 2005. ${ }^{2}$ Saaski and Hartl, 1980. ${ }^{3}$ Tarau et al., 2007

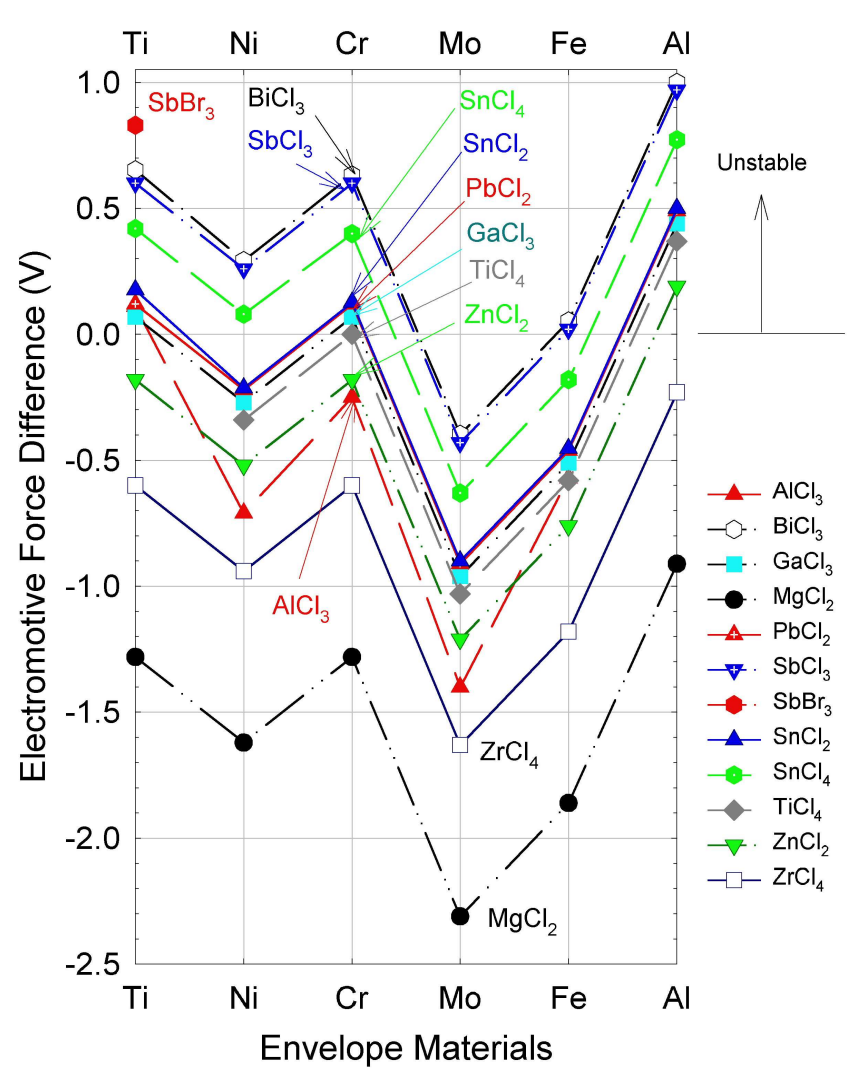

Figure 5. Electromotive Force Difference for Potential Halide/ Envelope Material Reactions. temperature). It should be noted that these results give a rough guide to the behavior of the halides, particularly when the envelope material is an alloy. The calculations above assume that the pure materials are in contact. In
As shown in Table 3, Tarau et al. compared the theoretical predictions with existing halide life test data, and obtained very good agreement in all but two cases. For Titanium/AlBr 3 , the theory predicts that the system was incompatible. However, TiAl was formed during the tests, which was not predicted by the theory. The theory predicts that $\mathrm{AlBr}_{3}$ should be compatible with pure aluminum. During the life tests, the $\mathrm{AlBr}_{3}$ attacked the grain boundaries in the aluminum alloys; clearly the reactivity of alloying additions in commercial alloys requires closer consideration.

\section{B. Envelope Material Selection}

The electromotive force difference was used to select envelope materials for halide life tests. Potential envelope materials include aluminum, aluminum alloys, titanium, titanium alloys, carbon steel, stainless steels, and the superalloys. The dominant metallic components for these envelopes include $\mathrm{Ti}, \mathrm{Ni}, \mathrm{Fe}, \mathrm{Cr}, \mathrm{Mo}$ and $\mathrm{Al}$. The following halides were examined: aluminum chloride, aluminum bromide, antimony chloride, antimony bromide, bismuth chloride, gallium chloride, lead chloride, magnesium chloride, tin dichloride, tin tetrachloride, zinc chloride and zirconium chloride.

The electromotive force differences are shown in Figure 5 and Table 4. Values above zero are unstable. The calculations used a temperature of potential difference is only a weak function of 
some cases, the alloy may have a stronger affinity for a component than the halide, preventing it from being dissolved.

Aluminum is the least suitable envelope material for the halides, with the exception of $\mathrm{Mg}$ and $\mathrm{Zr}$. From an EMF standpoint, the best envelope material would be molybdenum, followed by iron. All of the halides have strong negative potential differences with Mo and $\mathrm{Fe}$, hence have a low probability of spontaneous reaction. The results for iron suggest that carbon steel is a relatively stable envelope material for almost all the halides. Nickel, which is a major component in stainless steels and superalloys, shows a moderate lack of stability with bismuth trichloride, antimony trichloride and tin tetrachloride. However, it might be stable with the other halides including tin dichloride. Titanium has a higher tendency for corrosion, especially in the presence of antimony tribromide, bismuth trichloride, antimony trichloride and tin tetrachloride

Table 4. Electromotive Force Difference, Volts.

\begin{tabular}{|l|c|c|c|c|c|c|}
\hline & Ti & Ni & $\mathbf{C r}$ & Mo & Fe & Al \\
\hline $\mathrm{SbBr}_{3}$ & 0.83 & & & & & \\
\hline $\mathrm{BiCl}_{3}$ & 0.653 & 0.293 & 0.633 & -0.397 & 0.053 & 1 \\
\hline $\mathrm{SbCl}_{3}$ & 0.6 & 0.26 & 0.6 & -0.43 & 0.02 & 0.97 \\
\hline $\mathrm{SnCl}_{4}$ & 0.42 & 0.08 & 0.4 & -0.63 & -0.18 & 0.773 \\
\hline $\mathrm{SnCl}_{2}$ & 0.177 & -0.213 & 0.127 & -0.9 & -0.453 & 0.5 \\
\hline $\mathrm{PbCl}_{2}$ & 0.12 & -0.22 & 0.12 & -0.91 & -0.46 & 0.49 \\
\hline $\mathrm{AlCl}_{3}$ & 0.11 & -0.71 & -0.25 & -1.4 & -0.57 & \\
\hline $\mathrm{GaCl}_{3}$ & 0.07 & -0.27 & 0.07 & -0.96 & -0.51 & 0.44 \\
\hline $\mathrm{ZnCl}_{2}$ & -0.18 & -0.52 & -0.18 & -1.21 & -0.76 & 0.19 \\
\hline $\mathrm{ZrCl}_{4}$ & -0.6 & -0.94 & -0.6 & -1.63 & -1.18 & -0.23 \\
\hline $\mathrm{MgCl}_{2}$ & -1.28 & -1.62 & -1.28 & -2.31 & -1.86 & -0.91 \\
\hline $\mathrm{TiCl}_{4}$ & & -0.34 & 0 & -1.03 & -0.58 & 0.37 \\
\hline
\end{tabular}

Table 5. Estimated Envelope/Halide Compatibility.

\begin{tabular}{|c|c|c|c|c|c|c|}
\hline & $\mathrm{Ti}$ & $\begin{array}{c}\text { Hastelloy } \\
\text { C2000 }\end{array}$ & $\begin{array}{c}\text { Hastelloy } \\
\text { C22 }\end{array}$ & $\begin{array}{c}\text { Hastelloy } \\
\text { B3 }\end{array}$ & $\begin{array}{c}\text { Carbon } \\
\text { Steel }\end{array}$ & Aluminum \\
\hline $\mathrm{BiCl} 3$ & 0 & 0 & 0 & 0 & 1 & 0 \\
\hline $\mathrm{GaCl} 3$ & 1 & 1 & 1 & 2 & 2 & 0 \\
\hline $\mathrm{SbCl} 3$ & 0 & 0 & 0 & 0 & 1 & 0 \\
\hline SbBr3 & 0 & No Data & No Data & No Data & No Data & No Data \\
\hline $\mathrm{SnCl} 4$ & 0 & 0 & 0 & 1 & 2 & 0 \\
\hline $\mathrm{SnCl} 2$ & 1 & 1 & 1 & 2 & 2 & 0 \\
\hline $\mathrm{AlCl} 3$ & 1 & 2 & 2 & 2 & 2 & No Data \\
\hline AlBr3 & 1 & No Data & No Data & No Data & No Data & 0 \\
\hline $\mathrm{MgCl} 2$ & 2 & 2 & 2 & 2 & 2 & 2 \\
\hline & No & & & & 2 & \\
\hline $\mathrm{TiCl} 4$ & Data & 2 & 2 & 2 & & 0 \\
\hline $\mathrm{PbCl} 2$ & 1 & 1 & 1 & 2 & 2 & 0 \\
\hline $\mathrm{ZnCl2}$ & 2 & 2 & 2 & 2 & 2 & 0 \\
\hline $\mathrm{ZrCl} 4$ & 2 & 2 & 2 & 2 & 2 & $\underline{2}$ \\
\hline
\end{tabular}


The data in Figure 5 was used to estimate the compatibility of halides with six different potential envelope materials, see Table 5 ( 0 is least compatible, and 2 is most compatible). Aluminum and titanium were examined because they are lightweight, and steel was considered because iron appears to be very compatible, see Figure 5 .

Hastelloy superalloys were identified as possible heat pipe wall materials: B-3 (Ni-Mo), C-2000 (Ni-Cr-Mo), and $\mathrm{C}-22$ (Ni-Cr-Mo-W). The procurement of the 3 superalloys was initially based on the great general corrosion behavior to acids or excellent stress corrosion cracking and pitting resistance reported on the alloys. The three alloys can be used to investigate the influence of ternary additions, e.g. the effect of $\mathrm{Mo}, \mathrm{Cr}$, or $\mathrm{W}$ to the heat pipe environment. Weldability was another critical factor that was considered, and in general the interest of using superalloys is the much higher specific strength to compete against the lower density Ti- or Al-alloys.

\section{Halide Life Tests}

\section{Experimental Set-Up}

Table 6 has the dimensions for the 4 sets, of life test pipes, titanium and 3 superalloys. A schematic of the titanium heat pipe with the thermocouples and heater block attached is shown in Figure 1. The fill tube is longer than normal, to allow for the heat pipe to be purged of excess gas (if necessary), then resealed.

Table 6. Titanium and Superalloy Heat Pipe Dimensions and Wick Properties.

\begin{tabular}{|c|c|c|c|c|}
\hline & $\mathrm{CP}-\mathrm{Ti}$ & $\mathrm{C} 22$ & $\mathrm{C} 2000$ & B3 \\
\hline Length & 8 in. $(20.3 \mathrm{~cm})$ & 8 in. $(20.3 \mathrm{~cm})$ & 8 in. $(20.3 \mathrm{~cm})$ & 8 in. $(20.3 \mathrm{~cm})$ \\
\hline O.D. & 0.75 in. $(1.905 \mathrm{~cm})$ & 1.049 in. $(2.664 \mathrm{~cm})$ & 1.049 in. $(2.664 \mathrm{~cm})$ & 1.049 in. $(2.664 \mathrm{~cm})$ \\
\hline I.D. & 0.652 in $(1.656 \mathrm{~cm})$ & 0.879 in $(2.233 \mathrm{~cm})$ & 0.879 in $(2.233 \mathrm{~cm})$ & 0.879 in $(2.233 \mathrm{~cm})$ \\
\hline Wick & $\begin{array}{l}50 \times 50 \text { mesh } \\
\text { CP-Ti Screen }\end{array}$ & $\begin{array}{c}80 \times 80 \text { mesh } \\
\text { C22 Screen }\end{array}$ & None & None \\
\hline Fill Tube & CP-Ti & $\mathrm{C} 22$ & $\mathrm{C} 22$ & $\mathrm{C} 22$ \\
\hline
\end{tabular}

The next step was to select the halides to be tested. From Table 5, the four halides that are believed to be most compatible with the superalloys were $\mathrm{AlBr}_{3}, \mathrm{GaCl}_{3}, \mathrm{SnCl}_{4}$, and $\mathrm{TiCl}_{4}$. $\mathrm{TiBr}_{4}$ is also believed to be compatible, based on its chemical similarity to $\mathrm{TiCl}_{4}$.

The test matrix is shown in Table 7. The superalloy pipes were tested with $\mathrm{AlBr}_{3}, \mathrm{GaCl}_{3}, \mathrm{SnCl}_{4}$, and $\mathrm{TiCl}_{4}$, but not with $\mathrm{TiBr}_{4}$. Since $\mathrm{TiBr}_{4}$ is significantly more expensive than $\mathrm{TiCl}_{4}$, it made sense to first determine if $\mathrm{TiCl}_{4}$ is compatible with the Superalloys.

Table 7. Operating Temperatures, Halides and Titanium/Therminol Life Tests.

\begin{tabular}{|l|c|c|c|c|}
\hline & $\mathrm{CP}-\mathrm{Ti}$ & $\mathrm{C} 22$ & $\mathrm{C} 2000$ & $\mathrm{~B} 3$ \\
\hline $\mathrm{AlBr}_{3}$ & - & $400{ }^{\circ} \mathrm{C}(673 \mathrm{~K})$ & $400{ }^{\circ} \mathrm{C}(673 \mathrm{~K})$ & $400{ }^{\circ} \mathrm{C}(673 \mathrm{~K})$ \\
\hline $\mathrm{GaCl}_{3}$ & $340{ }^{\circ} \mathrm{C}(613 \mathrm{~K})$ & $360{ }^{\circ} \mathrm{C}(633 \mathrm{~K})$ & $360{ }^{\circ} \mathrm{C}(633 \mathrm{~K})$ & $360{ }^{\circ} \mathrm{C}(633 \mathrm{~K})$ \\
\hline $\mathrm{SnCl}_{4}$ & - & $280{ }^{\circ} \mathrm{C}(553 \mathrm{~K})$ & $280{ }^{\circ} \mathrm{C}(553 \mathrm{~K})$ & $280{ }^{\circ} \mathrm{C}(553 \mathrm{~K})$ \\
\hline $\mathrm{TiCl}_{4}$ & - & $300{ }^{\circ} \mathrm{C}(573 \mathrm{~K})$ & $300{ }^{\circ} \mathrm{C}(573 \mathrm{~K})$ & $300{ }^{\circ} \mathrm{C}(573 \mathrm{~K})$ \\
\hline $\mathrm{TiBr}_{4}$ & $380{ }^{\circ} \mathrm{C}(653 \mathrm{~K})$ & - & - & - \\
\hline $\mathrm{Therminol} \mathrm{VP} 1$ & $406{ }^{\circ} \mathrm{C}(680 \mathrm{~K})$ & - & - & - \\
\hline
\end{tabular}

As shown in Table 3, $\mathrm{AlBr}_{3}$ was previously shown to be incompatible with titanium. $\mathrm{TiCl}_{4}$ was already shown to be compatible with titanium, so $\mathrm{TiBr}_{4}$ was put on test in a titanium envelope. Table 5 shows that $\mathrm{SnCl}_{4}$ was predicted to be incompatible with $\mathrm{CP}-\mathrm{Ti}$, so it was not tested.

\section{Life Test Experimental Results}

Operating temperatures for the heat pipes are shown in Table 7. The operating temperature was set based on the vapor pressure, and the allowable stresses in each heat pipe as a function of temperature. During the life tests, the 
temperature of the evaporator and condenser for each heat pipe are monitored, to detect any problems. It is possible that oxygen can affect the outside of the titanium pipes during the test. To prevent this problem, the life tests are conducted inside a box that is purged with argon. During the life test, temperatures are monitored to detect the formation of non-condensable gas. The Thermocouple set-up is shown in Figure 1. One thermocouple is located just above the heater block; the other two are located in the heat pipe condenser. Once a week, temperatures are monitored. Any non-condensable gas will show up as a cold end on the heat pipe.

The $\mathrm{GaCl}_{3} /$ superalloy pipes all leaked at the pinchoff weld after roughly one week of operation at $360^{\circ} \mathrm{C}(633 \mathrm{~K})$. Note that all of the superalloy pipes used a $\mathrm{C} 22$ fill tube, since that was more readily available. A picture of the three fill tubes is shown in Figure 6.

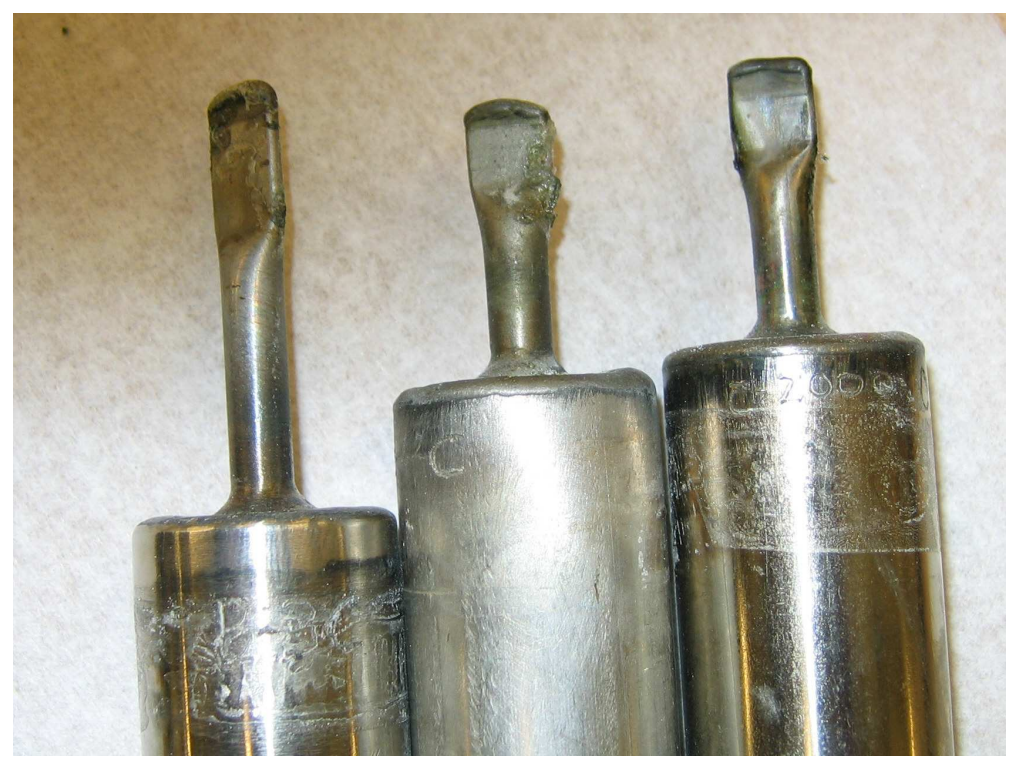

Figure 6. The $\mathrm{GaCl}_{3}$ heat pipes leaked at the pinch-off after one week. Note that all of the pinch-offs used $\mathrm{C}$ 22 tubing.

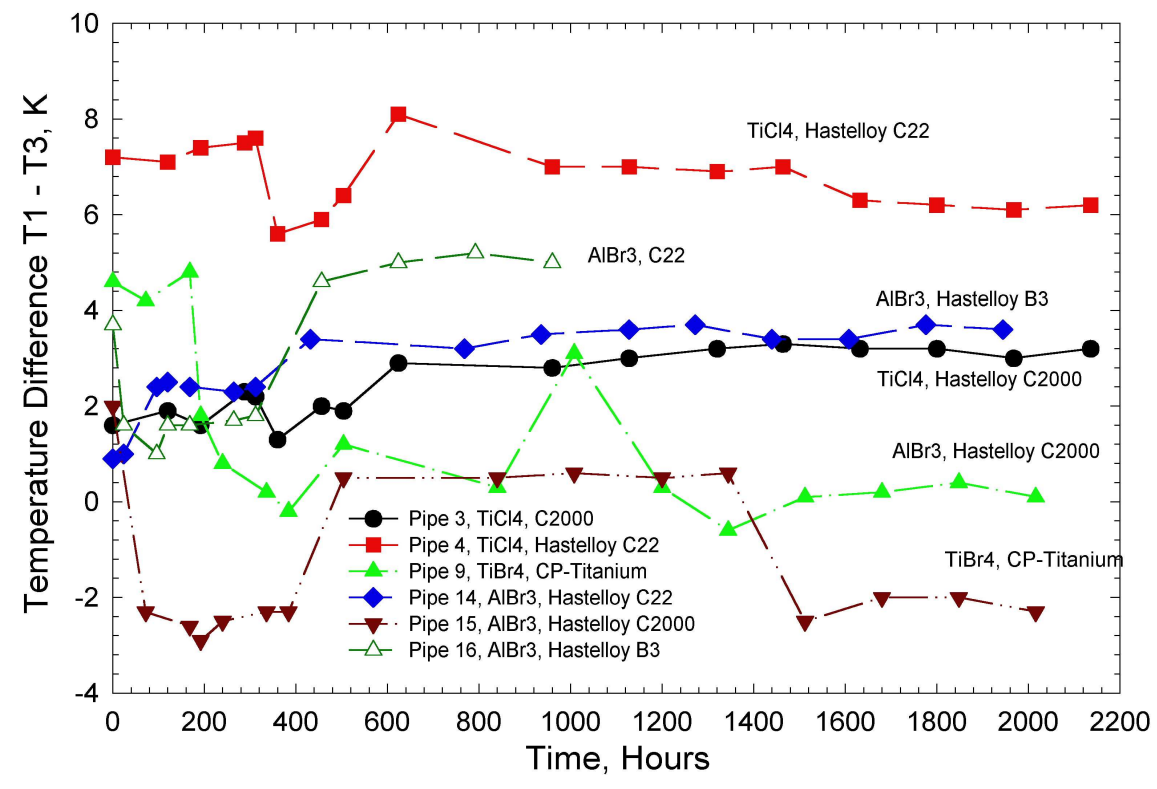

Figure 7. Initial Results, Halide Heat Pipes with Low $\Delta T$. 
Preliminary life test results for the halides and Therminol tests are shown in Figures 7 and 8. After 3,500 hours the $\mathrm{AlBr}_{3}, \mathrm{TiCl}_{4}$, and $\mathrm{TiBr}_{4}$ heat pipes have a low $\Delta \mathrm{T}$, indicating that non-condensable gas generation is not a problem $\left(\mathrm{TiCl}_{4}\right.$ with Hastelloy $\mathrm{B} 3$ has a higher $\left.\Delta \mathrm{T}\right)$. The $\mathrm{SnCl}_{4} /$ superalloy, $\mathrm{GaCl}_{3} /$ titanium pipes, and Therminol/titanium pipes all have a much higher $\Delta \mathrm{T}$.

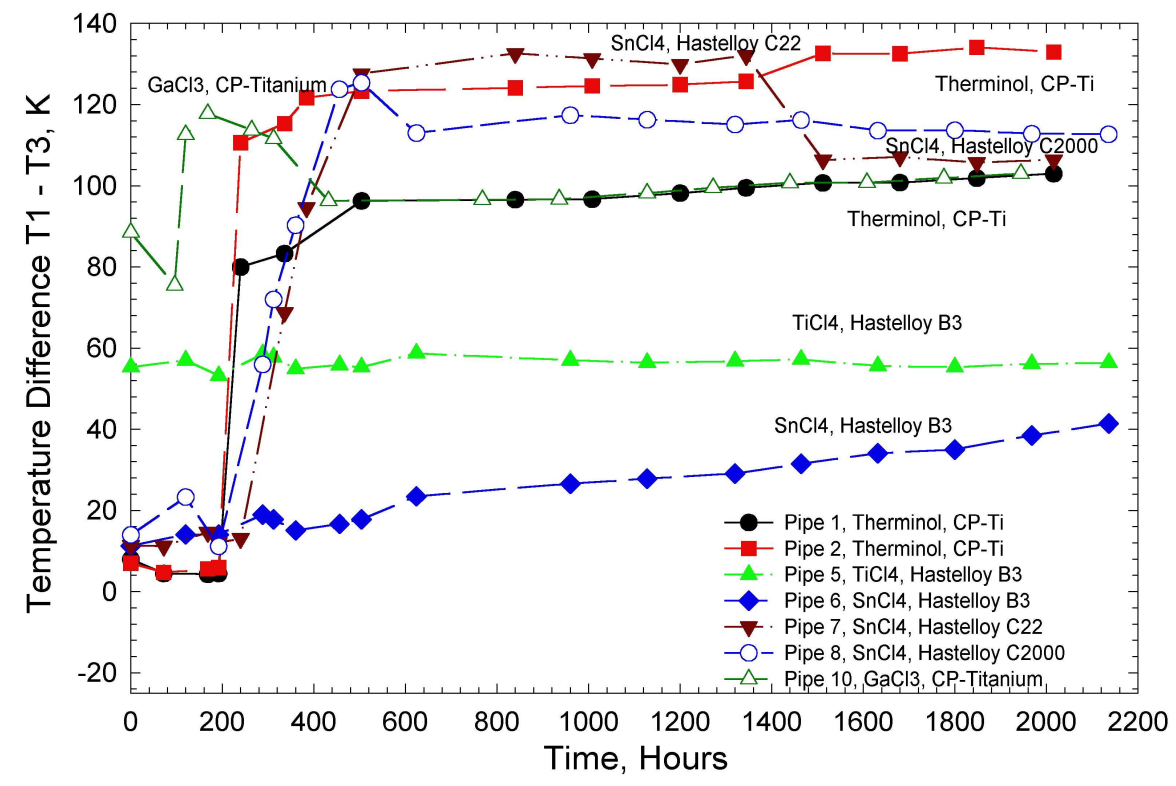

Figure 8. Initial Results, Halide and Therminol Heat Pipes with High $\Delta T$.

\section{Eutectic Diphenyl/Diphenyl Oxide Life Tests}

Eutectic Diphenyl/Diphenyl Oxide is a intermediate temperature fluid that is sold under the trade names of Dowtherm A and Therminol VP-1. Therminol VP-1 heat pipes were life tested at three different operating temperatures to test the degradation of the working fluid as a function of temperature. The manufacturer of Therminol states that a general rule, half of the fluid's life is lost for every $10^{\circ} \mathrm{C}$ above the maximum film temperature of $420^{\circ} \mathrm{C}$. Therefore, Therminol VP-1 was tested at three temperatures, two temperatures where it would be expected to last a long time, 350 and $400^{\circ} \mathrm{C}$, and at a temperature at which its life would be significantly reduced, $450^{\circ} \mathrm{C}$. At $450^{\circ} \mathrm{C}$ the fluid life should be under a year. Details of the life test pipes are shown in Table 8 . A life test pipe with its screen wick installed is shown in Figure 9.

Table 8. Therminol VP-1/Stainless Steel Life Test Pipes

\begin{tabular}{|l|c|}
\hline Working Fluid & Therminol VP-1 \\
\hline Operating Temperature & $350,400,450^{\circ} \mathrm{C}$ \\
\hline Material & $304 \mathrm{~L} \mathrm{SS}$ \\
\hline O.D. & $2.67 \mathrm{~cm}$ \\
\hline I.D. & $2.09 \mathrm{~cm}$ \\
\hline Length & $30.5 \mathrm{~cm}$ \\
\hline Screen & 100 mesh Stainless Steel \\
\hline Wraps & 1 \\
\hline
\end{tabular}




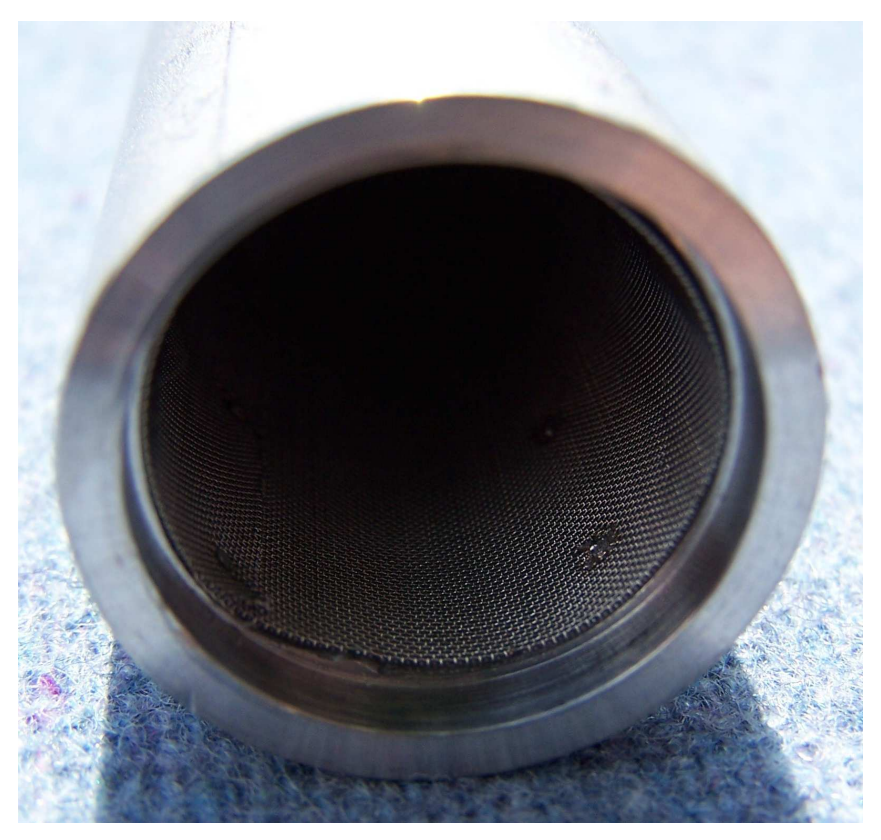

Figure 9. A screened 304 stainless steel life test heat pipe for the Therminol VP-1 life tests is pictured. The 3/4 inch Schedule 40 life test pipes are $30.5 \mathrm{~cm}$ long.

The temperature of the Therminol life test pipes was actively controlled, since life is very sensitive to temperature once the pipes are above $420{ }^{\circ} \mathrm{C}$. A schematic of the experimental setup is shown in Figure 10 . During the life tests, $\Delta \mathrm{T}$ between the evaporator and condenser of the heat pipe was monitored. Gas generated will build up in the condenser, preventing the working fluid from reaching the top of the condenser. The temperature of the heat pipe condenser will then fall relative to the evaporator, creating an increase in $\Delta \mathrm{T}$.

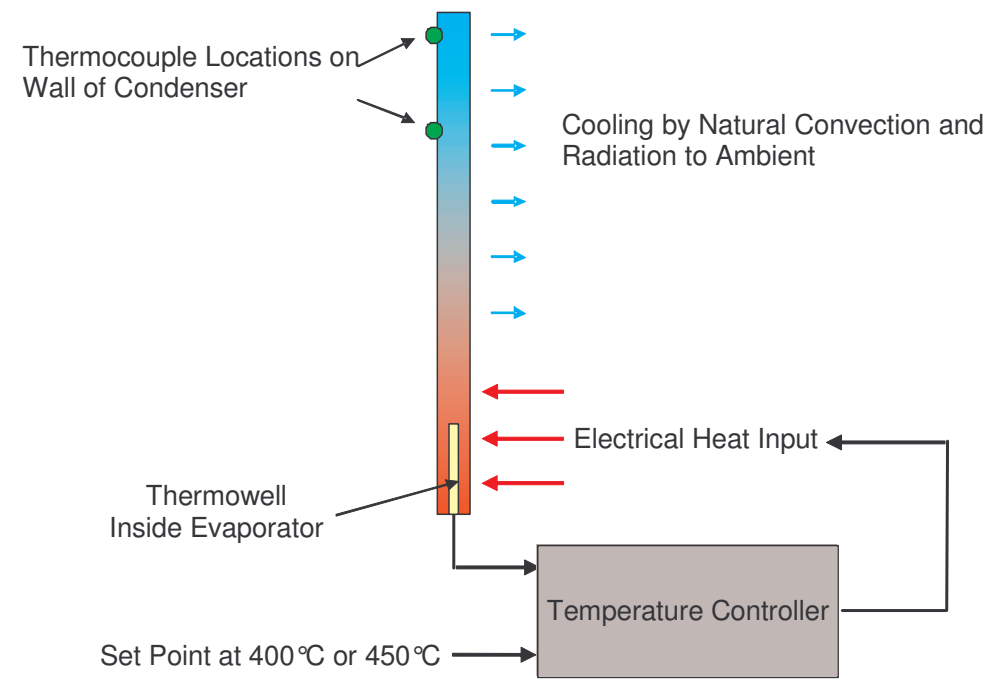

Figure 10. Therminol-VP-1/Stainless Steel Life Test Setup.

As shown in Figure 11, the life test pipes operating at $450^{\circ} \mathrm{C}$ showed a significant increase in $\Delta \mathrm{T}$ after only 90 hours, most likely caused by excess non-condensable gas. These pipes were taken off life test and purged, then put back on life test. Non-condensable gas generation continued at a high rate. The $450{ }^{\circ} \mathrm{C}$ pipes were taken off life test after 300 hours and analyzed. Figure 12 shows a sectioned heat pipe. As shown in the figure, a portion of the Therminol charred during the life test. 


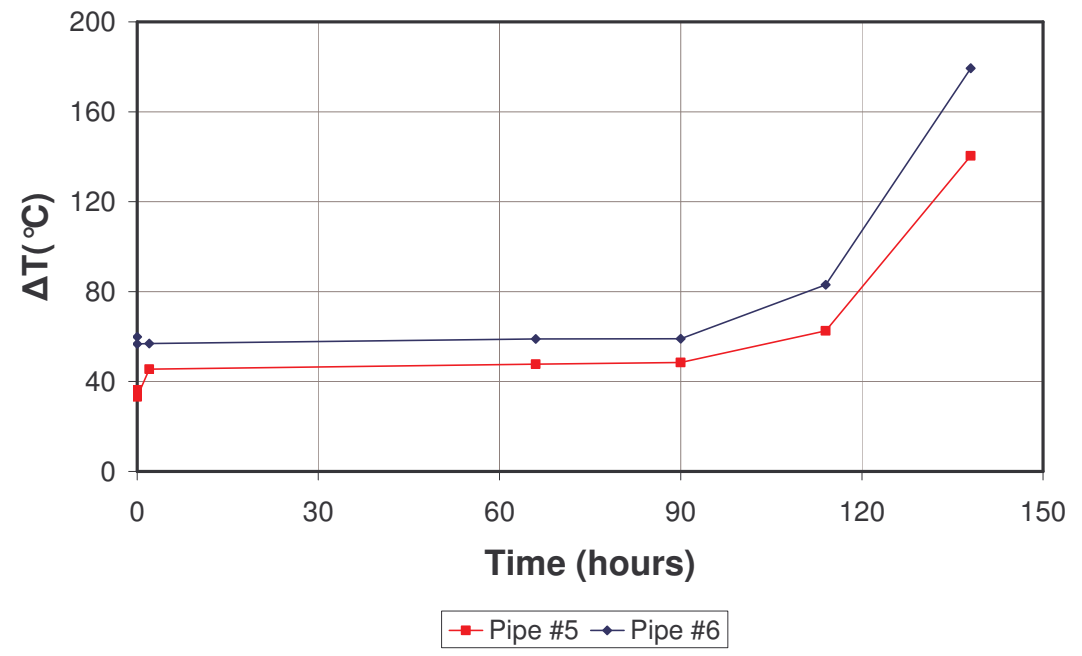

Figure 11. A chart showing life test data for Therminol VP-1/Stainless Steel heat pipes operating gravity aided at $450^{\circ} \mathrm{C}$ is shown. After 130 hours the pipes appear to have generated non-condensable gas as the $\Delta \mathrm{T}$ from the evaporator to the top of the condenser increased significantly.

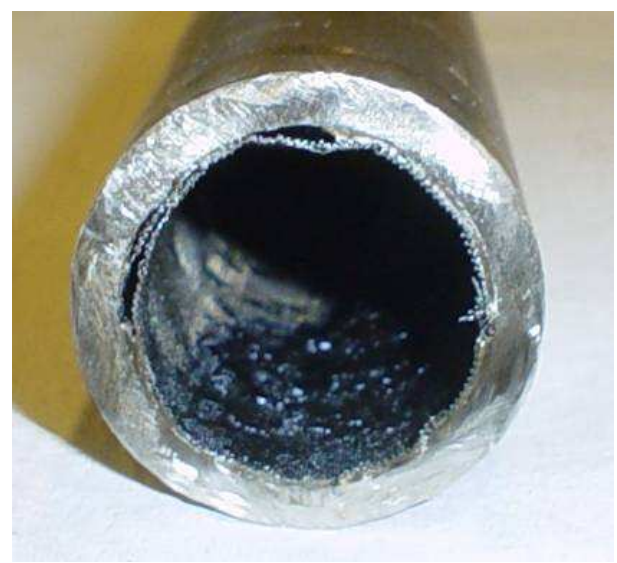

Figure 12. Picture of Therminol/stainless steel life test pipe taken off life test after 300 hours at $450^{\circ} \mathrm{C}$.

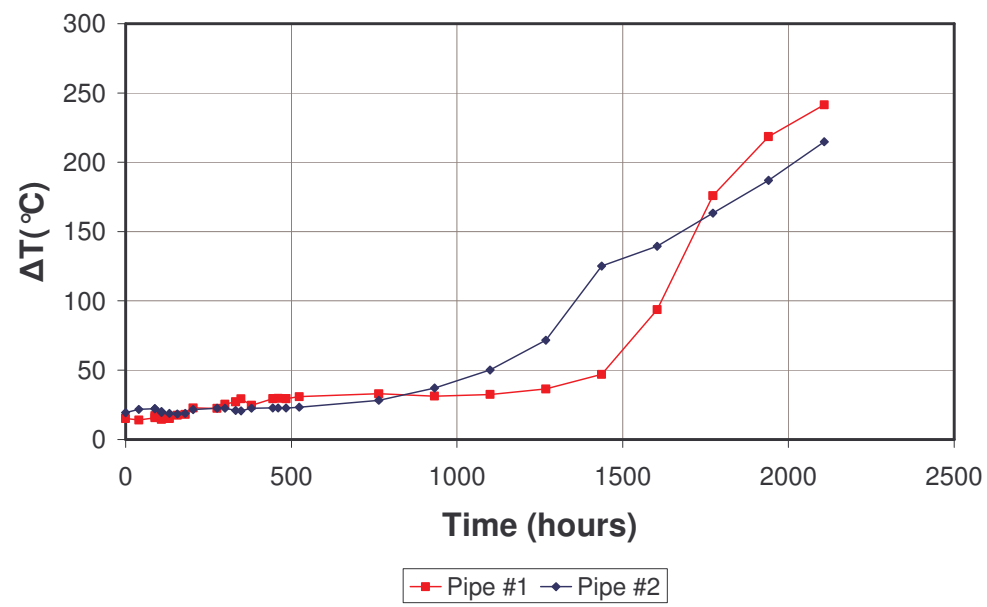

Figure 13. Therminol VP-1/Stainless Steel heat pipes operating gravity aided at $400^{\circ} \mathrm{C}$ show significant gas generation after roughly 1000 hours of operation. 


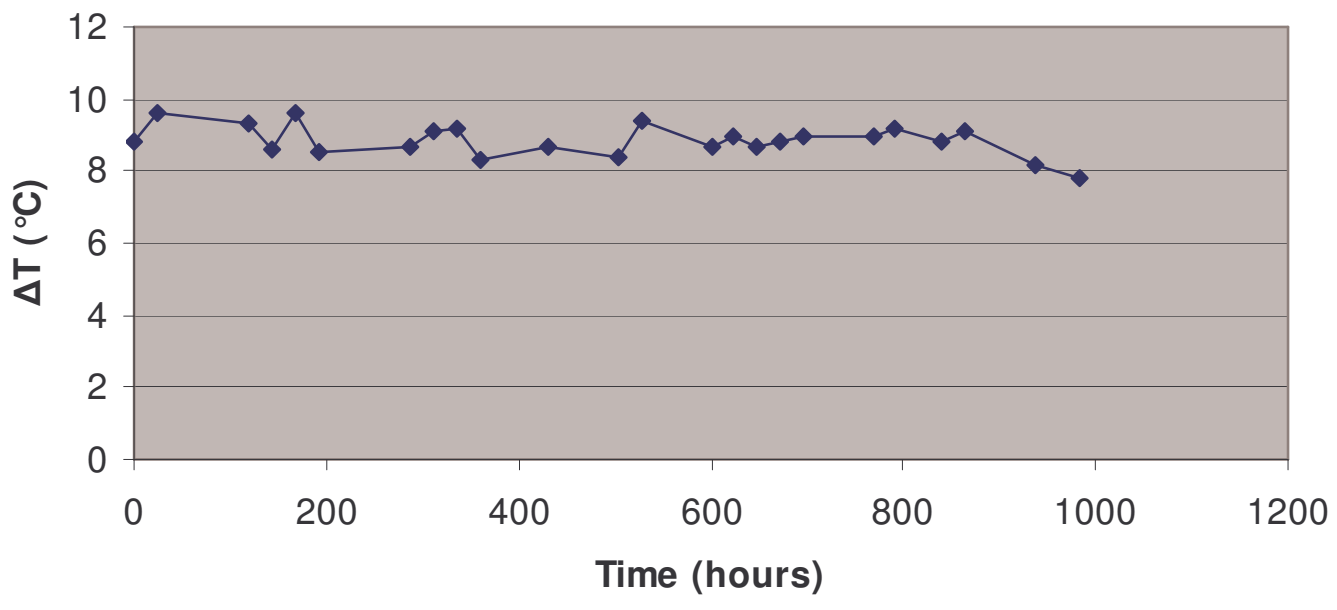

Figure 14. Therminol VP-1/Stainless Steel heat pipes operating gravity aided at $345^{\circ} \mathrm{C}$ show no signs of gas generation after operating for roughly 1000 hours.

Life tests results for the pipes operating at $400^{\circ} \mathrm{C}$ are shown in Figure 13. These heat pipes showed high gas generation rates after roughly 1000 hours of operation. Life tests for a pipe operating at $345^{\circ} \mathrm{C}$ are shown in Figure 14. Currently, they have operated for roughly 1000 hours, and show no signs of gas generation.

As discussed above, two CP-titanium life tests are currently being conducted at $406^{\circ} \mathrm{C}(680 \mathrm{~K})$ with Dowtherm A (which is the same mixture as Therminol). These heat pipes showed significant gas generation after several hundred hours of testing, see Figure 8.

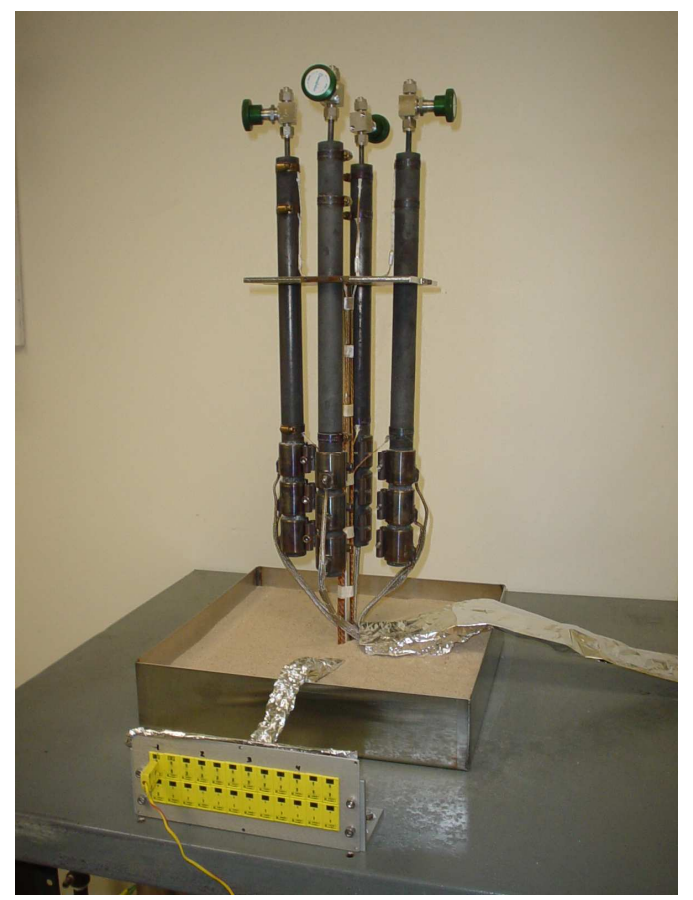

Figure 15. Cesium Copper/Nickel and Monel life test heat pipes.

\section{Cesium Life Tests}

Sarraf, Bonner, and Colahan (2006) recently examined a variable conductance heat pipe (VCHP) heat exchanger application with cesium as the working fluid. Cold sea-water was a potential coolant for the heat pipes (with a large $\Delta \mathrm{T}$ between the heat pipe interior and the water). Monel and copper-nickel are known to resist sea water corrosion, so they were potential heat pipe envelope materials. 
Early experience in the thermionics industry indicated that cesium was compatible with OFHC copper at temperatures up to $670 \mathrm{~K}\left(400^{\circ} \mathrm{C}\right)$ (Ernst, 2007). The cesium was contained in a copper vessel, and was supplied to the thermionics to lower the work function. In this application, the mass transfer of the cesium was very low.

Since there was no known life test data between cesium and Monel or copper-nickel, heat pipes were fabricated with Monel 400 and 70/30 copper/nickel envelopes. Two heat pipes of each material were fabricated from 3/4 inch Schedule 40 pipe $(2.67 \mathrm{~cm}$ O.D., $0.287 \mathrm{~cm}$ wall thickness). Each heat pipe was $45.7 \mathrm{~cm} \mathrm{long}$, with a $15.2 \mathrm{~cm}$ evaporator and a $30.5 \mathrm{~cm}$ condenser. A picture of the heat pipe setup is shown in Figure 15.

Two of the pipes were operated for 1000 hours and then dissected to look for signs of incompatibility. The remaining two have been on test for over 2500 hours, with plans to continue the tests indefinitely. Figure 16 plots the temperature differences between the evaporator and condenser sections of the heat pipes. Plotting the temperature differences this way is used to monitor non-condensable gas build up in the pipes. Build up of noncondensable gas can be seen as an increase in the temperature difference because as the non-condensable gas increases it blankets off the condenser, decreasing the heat transfer to the region and the temperature in the region. Since the temperature differences have not increased over time, it signifies that there has not been an appreciable build up of non-condensable gas.

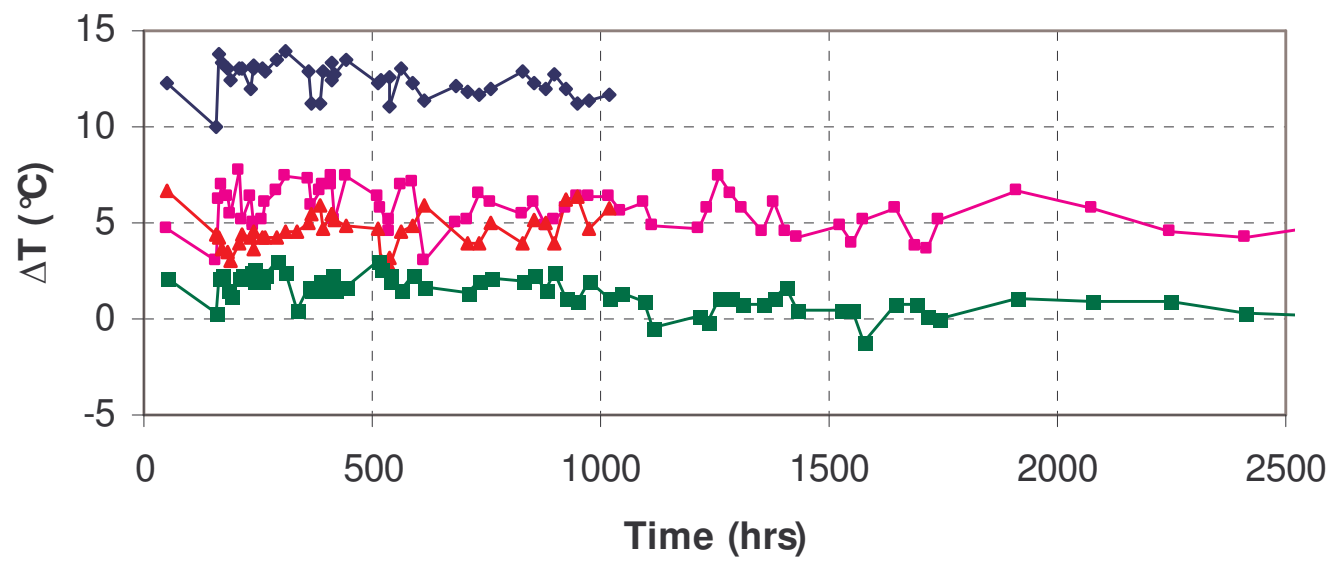

$\multimap$ Monel \#1 $\rightarrow$ Monel \#2 $\multimap \mathrm{Cu} / \mathrm{Ni} \# 1 \rightarrow \mathrm{Cu} / \mathrm{Ni} \# 2$

Figure 16. Cesium Heat Pipe Life Test Data at $475^{\circ} \mathrm{C}$.
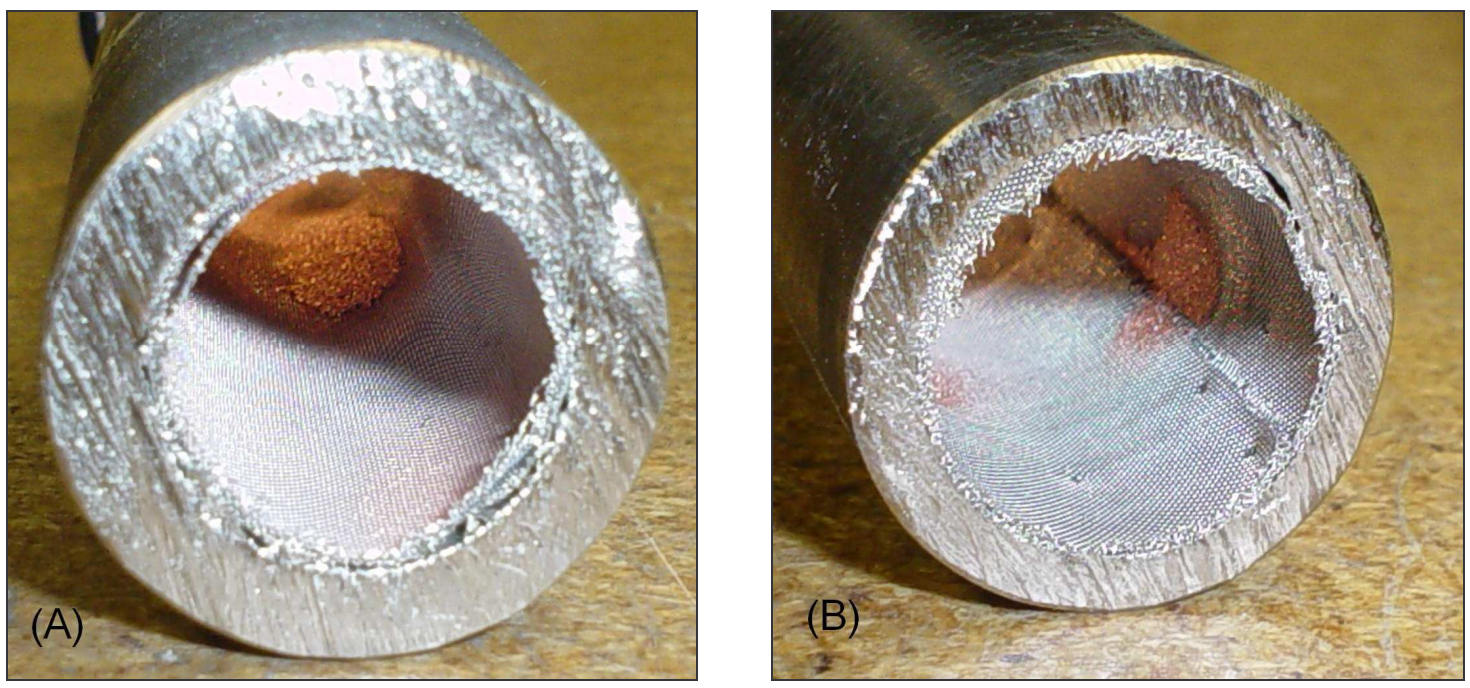

Figure 17. (A) Evaporator section of Monel life test pipe after operating at $475^{\circ} \mathrm{C}$ for 1000 hours with cesium. (B)Copper/nickel 70/30 heat pipe at same conditions. 
At 1,000 hours, one each of the Monel and copper/nickel heat pipes were taken off life test to be analyzed. The pipes were oriented upside down and the cesium was distilled from the heat pipe into another vessel. The pipes were then cut open to qualitatively analyze the wick and pipe wall for deterioration from the cesium working fluid.

Shown in Figure 17 is a picture of the inside of the evaporator of these pipes. Notice the build-up of copper in some sections (this is not seen in the condenser sections.) This phenomenon has been witnessed in other alkali metal pipes with alloy heat pipe envelopes. The corrosion mechanism is solubility of the wall material in the working fluid, cesium. Pure cesium vapor travels to the condenser end of the heat pipe. This pure vapor condenses into pure liquid. The pure liquid dissolves some of the wall material in the condenser. The working fluid then carries the dissolved metal to the evaporator. When the cesium is vaporized again, the dissolved metal remains behind. This continuous process of dissolving and transferring metal from the condenser to the evaporator will eventually lead to clogging of the wick structure in the evaporator and ultimately to corrosion through the condenser wall thickness. This is a slow process and may take years to affect the performance of a heat pipe constructed of Schedule 40 pipe; however, the magnitude of copper transferred in only 1000 hours is quite significant and Monel/Cesium or 70/30 Copper/Nickel/Cesium are not recommended for long life operation at the temperatures of interest for this application. 300 Series Stainless Steels have been shown to be compatible with cesium for 1000's of hours with no sign of degradation or solubility corrosion, and would be a better material/working fluid choice.

\section{Conclusion}

Water life test pipes have been fabricated with commercially pure (CP) titanium, Monel K-500, Monel 400, and various titanium alloys. $\mathrm{CP}-\mathrm{Ti}$ and Monel pipes currently have operated for 2.3 years. These pipes continue to operate successfully, with a small amount of gas generation in the CP-Ti pipes. Life test pipes with titanium alloys are also underway, with operating times of up to 1.3 years. Titanium/water and Monel/water heat pipes can be considered a mature or mainstream technology that is ready for widespread application.

A theoretical model based on electromotive force differences was used to predict the compatibility of halide working fluids with envelope materials. The envelope material halide should have a lower decomposition potential than the working fluid halide. $\mathrm{AlCl}_{3}$ and $\mathrm{TiCl}_{4}$ have a high decomposition potential, so should be good working fluids. Molybdenum and iron have a low decomposition potential, so should be good envelope materials. Life tests were conducted with these envelopes and five different halides: $\mathrm{AlBr}_{3}, \mathrm{GaCl}_{3}, \mathrm{SnCl}_{4}, \mathrm{TiCl}_{4}$, and $\mathrm{TiBr}$. The $\mathrm{GaCl}_{3}$ /superalloy pipes failed at the $\mathrm{C} 22$ pinch-offs after a week. After 2000 hours the $\mathrm{AlBr}_{3}, \mathrm{TiCl}_{4}$, and $\mathrm{TiBr}_{4}$ heat pipes have a low $\Delta \mathrm{T}$, indicating that non-condensable gas generation is not a problem $\left(\mathrm{TiCl}_{4}\right.$ with Hastelloy $\mathrm{B} 3$ has a higher $\Delta \mathrm{T})$. The $\mathrm{SnCl}_{4} /$ superalloy and $\mathrm{GaCl}_{3} /$ titanium pipes have a high $\Delta \mathrm{T}$.

Life tests were conducted with eutectic diphenyl/diphenyl oxide (Therminol VP-1/Dowtherm A) in 304L stainless and CP-titanium pipes. Gas was generated in the tests at $673 \mathrm{~K}\left(400^{\circ} \mathrm{C}\right)$ and above. A test with $304 \mathrm{~L}$ stainless steel at $618 \mathrm{~K}\left(345^{\circ} \mathrm{C}\right)$ does not show signs of gas generation after 1000 hours.

Cesium was tested with Monel 400 and 70-30 copper/nickel heat pipes operating near $750 \mathrm{~K}\left(480^{\circ} \mathrm{C}\right)$. These materials are not suitable for long term operation, due to copper transport from the condenser to the evaporator.

\section{Acknowledgments}

The water and halide life tests were sponsored by NASA Glenn Research Center under Contracts NNC05TA36T, and NNC06CA74C. Duane Beach was the Technical Monitor. Chris Stover and Rod McClellan were the technicians on the program. The cesium and stainless steel - eutectic diphenyl/diphenyl oxide life tests were sponsored by the Department of the Navy (Naval Sea Logistics Center) under Contract N65538-05-M-0139. Dennis Colahan was the Technical Monitor. We would also like to thank Cheryl Bowman and David Ellis of NASA Glenn Research Center for helpful discussions about the fluids and materials.

\section{References}

Anderson, W. G., "Intermediate Temperature Fluids for Heat Pipes and LHPs," Proceedings of the 2007 IECEC, AIAA, St. Louis, MO, June 25-27, 2007.

Anderson, W. G., Dussinger, P. M., Bonner, R. W., and Sarraf, D. B., "High Temperature Titanium-Water and Monel-Water Heat Pipes," in the proceedings of the $4^{\text {th }}$ International Energy Conversion Engineering Conference and Exhibit (IECEC), American Institute of Aeronautics and Astronautics, Reston, VA, 2006, Paper No. AIAA-2006-4113.

Anderson, W.G., Rosenfeld, J.R., Angirasa, D., and Mi, Y., "The Evaluation of Heat Pipe Working Fluids In The Temperature Range of 450 to 750 K," Proceedings, STAIF-2004, pp. 20-27, Albuquerque, NM, February 8-12, 2004.

Devarakonda, A. and Anderson, W.G., "Thermo-Physical Properties of Intermediate Temperature Heat Pipe Fluids," STAIF 2005, Albuquerque, NM, February 13-17, 2005. NASA Report NASA/CR-2005-213582, available from the NASA Glenn Technical Reports Server, http://gltrs.grc.nasa.gov/. 
Ernst, D. M., personal communication, 2007.

Jaworske, D.A., personal communication, 2007.

Locci, I. E., Devarakonda, A., Copeland, E. H., and Olminsky, J. K., "Analytical and Experimental Thermo-Chemical Compatibility Study of Potential Heat Pipe Materials," Proceedings of the 2005 IECEC, San Francisco, CA, August 15-18, 2005.

Saaski, E. W., and Owzarski, P. C., Two-Phase Working Fluids for the Temperature Range $50^{\circ}$ to $350^{\circ} \mathrm{C}$, NASA CR135255, NASA Lewis Research Center, Cleveland, OH, 1977.

Saaski, E. W., and Hartl, J. H., Two-Phase Working Fluids for the Temperature Range 50 to $350^{\circ} \mathrm{C}$, NASA CR-159847, NASA Lewis Research Center, Cleveland, OH, 1980.

Sanzi, J.L., "Thermal Performance of High Temperature Titanium - Water Heat Pipes by Multiple Heat Pipe Manufacturers," Space Technology and Applications International Forum (STAIF-07), American Institute of Physics, Melville, New York, 2007.

Sarraf, D. B., Bonner, R. W., and Colahan, D., "Passive Thermal Management for a Fuel Cell Reforming Process," Proceedings of the 2006 IECEC, AIAA, San Diego, CA, June 26-29, 2006.

Tarau, C., Sarraf, D. B., Locci, I. E., and Anderson, W. G., "Intermediate Temperature Fluids Life Tests - Theory," Proceedings, STAIF 2007, Albuquerque, NM, February 11-15, 2007. 